tage in respect to the points raised here with the figure of the external anatomy of the adult on plate 73 in my "Sketch of the Life-Histr,ry of the Oyster," already cited.

Mr. Cunningham's inference that the left valve, usually regarded as the lower one, is really the upper, because he finds worm-tubes and hydroids most abundant on the convex or left valve, is founded upon an imperfect acquaintance with the habits of the oyster. For, if living oysters are thrown into the water they will invariably fall upon the bottom with the left valve downward. If dead oyster-shells-free valves-be similarly thrown into the water, they will invariably fall with the hollow side up, and the convex one down. And furthermore, both living and dead shells remain in just the position in which they fall. Dead shells sown as cultch, or collectors, fall in such a position, and most of the spat is "caught" on the exposed parts of the under surface of such shells, whereas little is found on the upper surface. The reason for this is that the sediment which is deposited on the upper surfaces, asphyxiates the young oysterfry and the other larvæ which affix themselves before they can become established and strong enough to resist its effects. The affixed organisms on the exposed inclined under surfaces of the shells, are, on the other hand, protected from the accumulation of sediment.

It is also well known that the right valve of the oyster is always the most deeply pigmented, while the lower or left one is paler. This is always the case when oysters lie almost flat on the bottom. When crowded together on the natural banks in a vertical position, there is less difference between the colours of the valves. This difference is obviously due to some influence exerted by the position of the aspects of the body of the animal in respect to light, the same as in land and aquatic animals generally. I would conclude, for this last reason alone, that the right valve of the oyster is normally always uppermost, were it not for the fact that I have observed all the stages of transition from the spat to the adult condition in confirmation of such a conclusion. It is true that many young oysters have the right valve looking down when allowed to grow upon cultch or shells which have been sown upon the bottom to favour the collection of the spat, but that circumstance by no means subverts the conclusions of such cautious and careful observers as Brooks, Woodward, Jeffrey, Huxley, Horst, and others.

Smithsonian Institution, Washington, U.S.A., JOHN A. RYDER November I I

\section{The Rotation Period of Mars}

ONE or two points in Prof. Bakhuysen's investigation of the rotation period of Mars require correction :-

First, my determination of the period, as finally corrected, was $24 \mathrm{~h} .37 \mathrm{~m}$. $22.72 \mathrm{~s}$., correct within 0.02s. The correction arose from the detection of a small clerical error. My final result was deduced from a comparison of observations by myself in 1873 , with observations by Kaiser in 1864, Madler in $1830-$ I837, Sir W. Herschel in the last quarter of the eighteenth century, Huyghens and Hooke in 1666. I have since used the best observations during the oppositions of $188 \mathrm{I}$ and $188_{3}$, without finding any occasion for changing my result even by onehundredth part of a second, though I place no reliance on the second decimal figure.

But, secondly, Prof. Bakhuysen, like Mr. Denning some time since, has taken Kaiser's result uncorrected for the clerical errors-very seriously affecting it-which I detected in 1873 . Kaiser counted three days too many in comparing Hooke's observation with his own: one day through a mistake in correcting for change of style, and two days (apparently) from counting the years $\mathbf{I} 700$ and $\mathbf{1} 800$ as leap-years. His this taking three days too many of terrestrial time had the effectsince three corresponding Martian rotations were taken in-of introducing a deficiency amounting to three times the excess of a Martian over a terrestrial day, that is, $3 \times 37 \mathrm{~m}$. 22.7s., or $67,28 \mathrm{I}$ tenths of a second. This, divided by the total number of Martian rotations, about 88,900 , gives as a correction about $0.077 \mathrm{~s}$. to be added to both Kaiser's estimates, making them respectively $24 \mathrm{~h} .37 \mathrm{~m} .22 \cdot 697 \mathrm{~s}$. and $24 \mathrm{~h} .37 \mathrm{~m} .22 \cdot 668 \mathrm{~s}$., the mean of which, $24 \mathrm{~h} .37 \mathrm{~m} .22 \cdot 6825 \mathrm{~s}$, is practically the same as the value I assigned, viz. $24 \mathrm{~h} .37 \mathrm{~m} .22 \cdot 7 \mathrm{~s}$

I think it probable that Schmidt (and perhaps Prof. Bakhuysen, too) followed Kaiser so far as the error of three days was concerned. It would naturally be taken for granted that this part of Kaiser's work was free from error. If I had not been determined to find out where and how Kaiser's calculations differed from my own, I should not have found out his mistake, for certainly one would not expect to find two large errors in a work períectly free from small ones. But so it was. I may remark that Prof. Newcomb, of Washington, went through my calculation, finding it correct, and that Kaiser really had made the mistake I indicated.

As this correction re-established what Kaiser had doubted, the accuracy of Hooke's observations, and of my own interpretation of them, Prof. Bakhuysen's correction is scarcely ad. missible. For a difference of o.06s., multiplied by 88,900 for the Martian rotations between Hooke and Kaiser in 1873 , gives a total discrepancy of an hour and a half, nearly all of which must be assigned to Hooke's observations and Huyghens' (which I brought into agreement with Hooke's by correcting Kaiser's one-day error for change of style).

5, Montague Street, Russell Square, W.C., November 23

\section{Beloit College Observatory}

MY attention has been called to a paragraph in NATURE (vol. xxxii. p. 514), which, quoting from Science, speaks of "the Astronomical Observatory of Beloit College as closed for lack of funds." it is not strange that you express surprise at this announcement. Permit me to say that it is positively untrue. So far as I can learn, the only authority for it is a strange and entirely unwarranted statement from our late Director. Mr. Tatlock's connection with our Observatory closed on July I last. Within one week of that date Mr. Charles A. Bacon was appointed his successor, and a few weeks later he appeared and took charge. He has already proved himself competent, both as an observer and as an instructor. New arrangements are made for both meteorological and astronomical observations, and special attention will be given to solar and spectroscopic work. Though not richly endowed, our "Smith Observatory" is well equipped, and under its present direction its facilities will be made helpful to both the advancement and the diffusion of science. A. L. CHA PIN

Beloit College, Wisconsin, October $3 \mathrm{I}$

\section{CONFERENCE OF DELEGATES OF CORRE- SPONDING SOCIETIES OF THE BRITISH ASSOCIATION, HELD AT ABERDEEN}

A NEW branch of the British Association glided unobtrusively into existence at Aberdeen, under the new rules passed in the previous year: I mean the Conference of Delegates of Corresponding Societies. The Committee to whom the general arrangements connected with this new branch is intrusted are now issuing a circular to the Corresponding Societies, signed by myself as its Chairman, and by Prof. Meldola as its Secretary, in which they give an account of the proceedings at Aberdeen, with comments thereon. Much of this will be of general interest, as it helps to explain the functions of the Conference, which, as the proceedings showed, were imperfectly understood by many of the delegates themselves. The report is too long to ask you to print it in full, and on the other hand its general purport is more easily seized by leaving out details. I therefore limit myself to sending you extracts from it, with connectinglinks of explanation to make them read continuously.

The Corresponding Societies Committee of the British Association beg to lay the following statement of work done at Aberdeen, with comments thereon, before the Presidents and Councils of the various Societies whose applications for enrolment as Corresponding Societies of the British Association had been granted.

The Conference of Delegates was held on Thursday, September Io, and on Tuesday, September 15, both meetings having been called at 3.15 p.m., and lasting in each case about one hour. 